\title{
Real-time PCR assay for rapid detection and quantification of Vibrio aestuarianus in oyster and seawater: A useful tool for epidemiologic studies
}

\author{
Denis Saulnier ${ }^{a,}{ }^{*}$, Sophie De Decker ${ }^{a}$ and Philippe Haffner ${ }^{a}$ \\ a Laboratoire de Génétique et Pathologie, IFREMER, av. du Mus de Loup, 17390 La Tremblade, France \\ *: Corresponding author : D. Saulnier, Tel.: +33 5467626 46; fax: +33 5467626 11, email address : \\ Denis.Saulnier@ifremer.fr
}

\begin{abstract}
:
Because Vibrio aestuarianus is known to cause serious infections in Pacific oyster Crassostrea gigas, a real-time PCR assay was developed targeting the dnaJ gene of this bacterium. Only $V$. aestuarianus strains isolated from $C$. gigas mortality events in different geographic areas and the reference strain tested positive, whereas no amplification products was obtained with type strains belonging to 23 other species of Vibrio. Sensitivity and reproducibility of the method were assessed using either seawater or oyster homogenate samples spiked with one $V$. aestuarianus strain. All these samples were stored at $-20^{\circ} \mathrm{C}$ in order to mimic retrospective or grouped natural sample analysis without quantification bias due to prolonged freezing. Analysis of standard curves revealed excellent correlation values between light microscopy cell enumerations and PCR Threshold Cycle (Ct) values, and acceptable PCR reaction efficiencies for all type of samples. Quantification curves of both sample types were equivalent, with a detection level as low as $1.6 \mathrm{~V}$. aestuarianus cells in the PCR reaction tube, corresponding to $1.6 \cdot 10^{2}$ cells ml ${ }^{-1}$ and $1.6 \cdot 10^{2}$ cells $\mathrm{mg}^{-1}$ in seawater and entire oyster samples, respectively, taking into account the dilution factor used for appropriate template DNA preparation. Comparison of PCR assay reproducibility according to the complexity of samples revealed that seawater samples gave more reproducible quantification measures than samples from oyster homogenate, with precision of measured $C t$ values inferior to 0.4 and 0.6 respectively at $99 \%$ confidence. Use of the real-time PCR assay allowed us to monitor $V$. aestuarianus load in oysters naturally infected with this pathogen. Furthermore, we were able to detect $V$. aestuarianus in samples of seawater in which oysters had been reared and in algal cultures used for feeding oysters. Because of the rapidity and reliability of the real-time PCR assay method used in this study, just a few hours are needed compared with the two days required using the classic culture method, this technique will be particularly valuable in mollusc pathology laboratories, for monitoring the source and course of infections by $V$. aestuarianus in pathogenesis and epidemiologic studies, as well as for designing appropriate prophylactic control measures.
\end{abstract}

Keywords: Crassostrea gigas; Oyster; Pathogen; Real-time PCR; Taqman; Vibrio; V. aestuarianus 


\section{Introduction}

Diseases caused by infectious agents pose threats to aquaculture worldwide. Cultivated oysters represent the main aquacultural production species of France and China, and are at risk to such infections in their rearing environment. Many oyster diseases have been reported to be caused by protozoa, fungi, viruses (Elston, 1993, McGladdery, 1999) as well as by bacteria, which were initially described mainly in larval stages of hatchery-produced oysters (Sinderman, 1990). More recently, bacteria causing disease in juvenile to adult stages have been reported and characterised. Roseovarius crassostreae was described as the etiological agent of juvenile oyster disease of Crassostrea virginica (JOD) occurring on the northern Atlantic coast of the United States (Boettcher et al., 1999, Boettcher et al., 2005). An actinomycete bacteria Nocardia crassostreae detected in North America and Japan was responsible for oyster summer mortality events in Pacific oyster, Crassostrea gigas (Friedman et al., 1998, Friedman et al., 1991). Furthermore, two Vibrio species, V. aestuarianus and $V$. splendidus were found to be associated with summer mortality phenomena of $C$. gigas oysters reared in France (Garnier et al., 2007, Gay et al., 2004, Labreuche et al., 2006a, Lacoste et al., 2001, Le Roux et al., 2002).

V. aestuarianus has frequently been associated with massive mortality events in Crassostrea gigas oysters occurring during summer. These events often occur when seawater temperatures reach $19^{\circ} \mathrm{C}$ on the French Atlantic coast, and affect mainly young individuals of 1 to 2 years in age (Garnier, et al., 2007). Classic bacteriology studies revealed that these moribund animals were predominantly infected with $V$. aestuarianus, found at septicaemic concentrations in the hemolymph but also in other oyster tissues, whereas apparently healthy oysters collected at the same locations generally only harboured a low load of $V$. aestuarianus cells in their tissues (Garnier, et al., 2007). The same authors demonstrated that a majority of $V$. aestuarianus strains found dominant in the hemolymph of moribund animals were virulent in experimental challenges, inducing more than $50 \%$ cumulative mortalities 5 days post injection. Some pathogenesis studies have emphasized their probable mode of action. A virulent $V$. aestuarianus strain (01/32) was shown to impair the function and survival of immunocompetent cells, known as hemocytes, by producing toxins. Treatment of hemolymph in vitro with extracellular products produced by this pathogenic strain was shown to induce a significant inhibition of both hemocyte adhesive properties and phagocytosis, and an enhancement of reactive oxygen species (Labreuche, et al., 2006a). Similar results were found with an in vivo approach performed by experimental infection using the 01/32 bacterial strain, which also demonstrated a deregulation in the hemocyte oxidative metabolism (Labreuche et al., 2006b).

Traditional identification and quantification methods currently used for Vibrio species associated with mortality events in organisms of aquacultural interest are based on the cultivability of bacteria on nonselective synthetic medium. Procedures are time-consuming and laborious, requiring long incubation times, and even though a few isolates are well characterized taxonomically, quantification is often extrapolated from the macroscopic or visual aspect of colonies on nutrient agar plates. Furthermore, these methods may underestimate the number of target bacteria because of natural microbial competitors present in analyzed samples. High levels of background microflora may also cause inefficiency as these produce confluent growth on the plating media that can mask the target bacteria. To overcome these drawbacks, DNA-based methods such as PCR are being increasingly used. PCR methods provide rapid, specific and sensitive analysis of targeted Vibrio, but do not make quantitative measurements (Paillard et al., 2006, Pang et al., 2006, Saulnier et al., 2000). To evaluate bacterial presence quantitatively, several investigators have developed quantitative PCR strategies in molluscs, but only for bacteria causing diseases in humans (Blackstone et al., 2003, Campbell and Wright, 2003, Gordon et al., 2008, Lyon, 2001, Nordstrom et al., 2007). The general principle of these methods lies in their ability to detect and quantify DNA targets by monitoring PCR product accumulation during the early exponential phase of amplification, indicated by increased fluorescence. Available chemistries include DNA-intercalating agent SYBR Green I and dual-labelled oligonucleotidic probe, hydrolysed by 5' exonuclease activity of Taq polymerase during elongation step. This latter method has been extensively used and offers an additional level of specificity, compared with primers used alone, due to the hybridization of fluorescent oligonucleotidic probe to a specific sequence of amplicon (Heid et al., 1996, Holland et al., 1991).

The goal of the current study was the development and evaluation of a real-time PCR assay that would provide a rapid, sensitive and quantitative method for the detection of $V$. aestuarianus cells in pure cultures, seawater and oysters. In order to allow retrospective or grouped sample analyses, which are particularly helpful in saving time during DNA extraction steps, real-time PCR assay was evaluated under conditions where samples were stored at $-20^{\circ} \mathrm{C}$ prior to analysis. To our knowledge, 
this is the first report on the development of a molecular-based method for the quantitative detection of a bacterial pathogen of a mollusc.

\section{Materials and methods}

\subsection{Bacterial strains and culture conditions}

A total of 34 bacterial strains, including $V$. aestuarianus $(n=11)$ and other Vibrio species reference strains $(n=23)$ was used to assess the specificity of the oligonucleotidic probe and primers (Table 1$)$. All $V$. aestuarianus strains, apart from the $V$. aestuarianus type strain (Tison and Seidler, 1983), were identified by $16 \mathrm{~S}$ gene sequencing and isolated from $C$. gigas reared in France and collected during mortality events occurring between 2003 and 2007.

All strains were cultured in Marine Broth (MB) purchased from Difco, prepared as peptone 4\%, yeast extract 1\% diluted in Sterile Artificial Sea Water (SASW 2.3\% NaCl, $20 \mathrm{mM} \mathrm{KCl}, 5 \mathrm{mM} \mathrm{MgSO}, 2 \mathrm{mM}$ $\mathrm{CaCl}_{2}$ ) from bacterial stock culture stored at $-80{ }^{\circ} \mathrm{C}$ and prepared as $15 \%(\mathrm{v} / \mathrm{v})$ glycerol suspensions in $\mathrm{MB}$. After incubation at $20{ }^{\circ} \mathrm{C}$ for $20 \mathrm{~h}$ under constant shaking, bacterial suspensions at stationaryphase were enumerated by light microscopy using a Malassez counting chamber.

\subsection{DNA extraction procedures}

For specificity assessment of the real-time PCR assay, total DNA from pure colonies cultured in MB $15 \%$ Agar medium was extracted by boiling. Briefly, one bacterial colony was picked up with a sterilized toothpick and resuspended in $100 \mu \mathrm{l}$ of ultra pure water (Sigma). This mixture was boiled for $10 \mathrm{~min}$ at $98{ }^{\circ} \mathrm{C}$ and then placed at $4{ }^{\circ} \mathrm{C}$ for few minutes before PCR assay. Five $\mu \mathrm{l}$ of the solution were used in duplicate as a PCR template.

For detection and quantification of $V$. aestuarianus by the real-time PCR assay, total DNA from all samples (either those obtained from the rearing environment or artificially spiked with Vibrio cells, see section 2.5 below) was extracted with a QIAmp DNA minikit (Qiagen). Samples of $200 \mu$ were centrifuged at $10000 \mathrm{~g}$ and $4{ }^{\circ} \mathrm{C}$ for $5 \mathrm{~min}$. After DNA extraction following manufacturer's instructions, pelleted DNAs were resuspended in $100 \mu \mathrm{l}$ or $10 \mathrm{ml}$ of ultra pure water for seawater and oyster samples, respectively, and stored at $-20^{\circ} \mathrm{C}$. DNA yield and purity were determined by spectrophotometry (Eppendorf).

\subsection{PCR primers and fluorogenic probe}

Oligonucleotide sequences were derived from the sequence alignment of the dnaJ housekeeping gene in different Vibrio species including $V$. aestuarianus type strain (Nhung et al., 2007). Primer 3 software was used to design a real-time PCR probe (Table 2) and forward and reverse PCR primers, taking into account optimal thermal and chemical conditions for PCR amplification compatible with probe hydrolysis based qPCR. The probe consists of an oligonucleotide dually labelled with a 5'reporter dye Texas Red and a downstream 3'-quencher dye BHQ-2 (Eurogentec). The probe and primers were assessed for species specificity using a BLAST search to determine homology to known sequences.

\subsection{V. aestuarianus real-time PCR assay conditions}

Real-time PCR assay was conducted on MX3000 Thermocycler (Stratagene) using Brilliant QPCR Core Reagent Kit (Stratagene). Each reaction was run in triplicate in a final volume of $25 \mu$ l containing various concentrations of DNA sample $(5 \mu \mathrm{l}), 5 \mathrm{mM} \mathrm{MgCl}, 200 \mu \mathrm{M}$ of each dNTP, $300 \mathrm{nM}$ of each primer, $200 \mathrm{nM}$ of oligonucleotidic probe and 1.25 units of hot start Sure Taq polymerase. The thermal cycle was performed with a two-step PCR protocol: 1 cycle at $95{ }^{\circ} \mathrm{C}$ for $10 \mathrm{~min}$ followed by 40 cycles at $95{ }^{\circ} \mathrm{C}$ for $15 \mathrm{~s}$ and $60^{\circ} \mathrm{C}$ for $90 \mathrm{~s}$. Fluorescence intensity was expressed in delta reporters (dR) after background subtraction. Threshold was set using amplification based algorithm from MX3000 software (Stratagene) for the initial plate. For other plates we used an interplate calibrator to set the threshold 
manually. Threshold Cycle (Ct) value corresponded to the PCR cycle number at which an increase in reporter fluorescence above a baseline signal was first detected.

\subsection{Quantification of V. aestuarianus in artificially spiked samples}

Oysters (from Prévost lagoon on French Mediterranean coast) and SASW samples were artificially spiked with an early stationary phase pure defined culture of $V$. aestuarianus 02/041 strain. The bacterial suspension was centrifuged at $3200 \mathrm{~g}$ for $10 \mathrm{~min}$ at $20^{\circ} \mathrm{C}$ and cells resuspended in SASW to obtain an optical density (OD) of 2, at a wavelength of $600 \mathrm{~nm}$. Quantification of bacterial cells by realtime PCR in spiked samples was compared with the enumeration of bacterial cells using a Malassez counting chamber.

All Crassostrea gigas oyster samples collected were stored at $-20^{\circ} \mathrm{C}$. After thawing, the whole flesh was recovered from the shell and rinsed with SASW. Fifteen animals were dissected into two equal parts in order to prepare three duplicated pools (5 half oysters in each pool). These pools were all diluted in SASW (1:10 w/v) and one replicate of each pool was seeded with $V$. aestuarianus 02/041 cells. Finally, all the six pools were crushed at $9500 \mathrm{r} / \mathrm{min}$ for $2 \mathrm{~min}$ using a conventional mixer. Each homogenate was stored at $-20^{\circ} \mathrm{C}$.

Three independent ten-fold serial dilutions of artificially spiked oyster homogenates were generated, using corresponding non-spiked pools as diluents. Dilutions were produced in $2 \mathrm{ml}$ and all samples were stored at $-20{ }^{\circ} \mathrm{C}$ prior to analysis. After these samples were thawed, only $200 \mu \mathrm{l}$ was used for DNA extraction. For SASW samples, the same procedure was performed on three serial dilutions, replacing oyster homogenate with SASW.

\subsection{Quantitative detection of indigenous V. aestuarianus}

Apparently healthy one-year-old $C$. gigas oysters were purchased from Fouras, Charente Maritime in France on May 16,2008 . Thirty oysters were immediately stored at $-20^{\circ} \mathrm{C}$. All the others were placed in a $200 \mathrm{~L}$ stabulation tank equipped with aerators, a closed seawater recirculation system and thermoregulation apparatus $\left(20^{\circ} \mathrm{C}+/-1^{\circ} \mathrm{C}\right)$. Animals were fed with a mixture of Isochrysis galbana and Chaetoceros gracilis and monitored over a two month period. Mortalities were observed and were attributed to $V$. aestuarianus, as the pathogen was isolated and characterized by classic culture and identification methods and found dominant in the hemolymph of the dying animals. Following the onset of mortalities, recently dead oysters were collected from the tank at different times; apparently healthy oysters were also collected to serve as controls. All these animals were stored whole at $-20^{\circ} \mathrm{C}$ until use. During the same period, seawater samples of different origins were collected in sterile plastic tubes and stored at $-20^{\circ} \mathrm{C}$. This sampling was done from different places around the oyster rearing facilities: samples were thus taken of Chaetoceros gracilis algae tanks, seawater distributed to oyster tanks and seawater from an oyster growout pond in the vicinity of the rearing facilities.

All these samples were prepared in exactly the same way as the spiked samples described above. Briefly, oysters were crushed in SASW, DNA extracted from a $200 \mu \mathrm{l}$ sample and pelleted DNA was finally resuspended in $10 \mathrm{ml}$ ultra pure water. For algae or seawater samples, DNA was extracted from a $200 \mu \mathrm{l}$ sample and resuspended in $100 \mu \mathrm{l}$ of ultra pure water. Indigenous $V$. aestuarianus load was evaluated by real-time PCR using standard curves.

\section{Results}

\subsection{Real-time PCR assay using dual labelled probe.}

Our PCR primers and real-time PCR probe were designed to target the more divergent nucleotidic regions of the dnaJ gene sequences from strains belonging to 57 Vibrio species (Genbank $n^{\circ}$ AB263017 to AB263073). Sequence alignment comparisons showed that the forward and reverse primer pair had 9 to 15 nucleotidic sites specific for $V$. aestuarianus type strain, out of 56 . Furthermore, the nucleotidic sequence of the probe targeted an additional codon present in $V$. aestuarianus and ten other Vibrio species, but lacking in most other Vibrio species $(n=46)$. However, the probe sequence encompassed at least 4 to $8 \mathrm{~V}$. aestuarianus specific nucleotides absent from the other ten Vibrio species displaying the additional codon. 
Species specificity of the real-time PCR assay was evaluated by testing several $V$. aestuarianus strains isolated during $C$. gigas mortality events and reference strains belonging to different Vibrio species, among which some were phylogenetically related to $V$. aestuarianus. The real-time PCR assay amplified the DNA of all the $V$. aestuarianus strains tested $(n=11)$, including the ATCC $35048^{\top}$ reference strain, and only the DNA of this species. No positive amplification signals were obtained with any of the non-V.aestuarianus strains $(n=23)$ tested in this study (Table 1$)$. Amplified PCR product size was verified by gel electrophoresis, visualizing a 266-bp long amplicon (not shown).

The three standard curves obtained in SASW samples spiked with $V$. aestuarianus strain 02/041, determined by enumeration on Malassez counter chamber and real-time PCR on purified DNA, showed excellent correlations (linear regression with $r^{2}$ coefficients of $0.996,0.993,0.997$ ) and acceptable PCR reaction efficacies $(96 \%, 97 \%, 100 \%)$ according to $\mathrm{Ct}$ values obtained in triplicate (data not shown). Because similar quantification curves were obtained in these three independent experimental replicates, $\mathrm{Ct}$ values from the three experiment replicates corresponding to the same bacterial dilution were treated collectively and gave a single quantification curve with correlation and PCR reaction efficacy of 0.995 and $98 \%$ respectively (Fig. 1). A linear range of values for PCR amplification was achieved for dilutions of pure bacterial suspensions ranging from $1.610^{8}$ to $1.610^{2}$ cells $\mathrm{ml}^{-1}$, corresponding to DNA extracts ranging from $10 \mathrm{\mu g} \mathrm{ml}^{-1}$ to $10 \mathrm{pg} \mathrm{ml}^{-1}$, as measured by spectrophotometry. Precision of measured $\mathrm{Ct}$ values is inferior to 0.4 at $99 \%$ confidence, as shown in figure 1. Repetition of these experiments, by the addition of a mixture of $V$. tapetis and $V$. splendidus type strains $\left(10^{5}\right.$ cells each) in all 02/041 cell dilutions prior to DNA extraction revealed that exogenous DNA had little or no influence on cycle threshold values (Fig. 2).

\subsection{Enumeration of V. aestuarianus in artificially inoculated oyster homogenate}

Real-time PCR assay on DNA extracted from the three pools of half oysters used as diluent in sensitivity assays yielded no amplification signals. The three corresponding pools of half oyster homogenates were seeded with pure cultures of $V$. aestuarianus strain 02/041 ranging from $1.610^{8}$ to

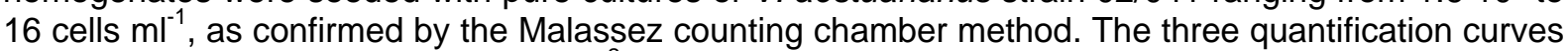
were similar, exhibiting correlations of $r^{2}=0.993,0.989$ and 0.99 and PCR reaction efficacies of $98 \%$, $88 \%, 95 \%$ when dilutions of pure bacterial suspensions ranged from $1.610^{8}$ to $1.610^{4} \mathrm{cells} \mathrm{ml}^{-1}$ (data not shown). Spectrophotometric analysis of the DNA content of extracted samples revealed different concentrations according to the oyster pools tested $\left(281,45,283 \mu \mathrm{g} \mathrm{ml}^{-1}\right)$. These DNA concentrations were not affected by artificial seeding with $V$. aestuarianus cells, whatever their dilution in the pools. Treatment of $\mathrm{Ct}$ values collectively yielded a single quantification curve with $\mathrm{Ct}$ precision values less than 0.6 at 99\% confidence (Fig. 3) and 94\% PCR efficacy. Comparison between collectively-treated quantification curves, obtained by artificial inoculation of either SASW or oyster homogenate, revealed similar detection levels of $V$. aestuarianus in the range $1.610^{4}$ to 1.6 cells by real-time PCR, taking into account the dilution factor used for appropriate template DNA preparation (1 or 100 respectively) (Fig. 4).

\subsection{Detection of $V$. aestuarianus in environmental samples}

All the tested samples were collected between May 16 and June 132008 at an oyster breeding facility, during an episode of oyster mortality. Twenty oysters were randomly sampled on arrival, which was one week before the onset of mortalities (May 23). At this point, $V$. aestuarianus was detected and quantified at a low level in a few individuals ( $\mathrm{n}=2$ among 20 tested animals). The bacterial load was 194 cells $\mathrm{g}^{-1}$ tissue in these two animals, according to the Ct values and standard curves of our real-time PCR assay. One week after the onset of mortalities, $V$. aestuarianus was detected in all moribund animals that were tested $(n=5)$, at a mean concentration of 10473 cells $\mathrm{mg}^{-1}$. In contrast, $V$. aestuarianus was only detected in 1 out of the 5 apparently healthy animals tested from the same sampling date, and at the very low concentration of 40 cells $\mathrm{mg}^{-1}$.

The seawater samples were taken (1) from algal cultures used for oyster feeding ( $n=3$, collected on May 30, June 4 and June 13), (2) from an oyster growout pond ( $n=1$, collected on May 16), and (3) from the water supply network of tanks where oyster mortalities were observed $(n=1$, collected on June 12). Interestingly, $V$. aestuarianus cells were detected in all these samples and ranged from 25 to 400 cells $\mathrm{ml}^{-1}$. 


\section{Discussion}

There are few ways to limit the detrimental effect of mollusc pathogens. Drug treatment is unconceivable in the open sea where animals are commonly reared, due to the dispersion or dilution of the molecules and their negative impact on the environment (Berthe, 2000). Furthermore, immune stimulation is impractical at present because we do not know enough about adaptive immunity mechanisms of these organisms (Flajnik and Du Pasquier, 2004). In this context, there is a need for rapid, quantitative and accurate measurements of target organisms, which will allow us to evaluate appropriate prophylactic and disease control strategies. $V$. aestuarianus is of particular concern as it has been seen to be responsible for mortality episodes in the Pacific oyster $C$. gigas.

PCR primers and a real-time PCR probe were designed to target the $V$. aestuarianus dnaJ gene that encodes a heat shock protein of $40 \mathrm{kDa}$. This gene has been shown to be a suitable target for identification of Vibrio species because it has a higher discriminatory power than the 16S rDNA gene and other housekeeping genes such as recA and rpoA (Nhung, et al., 2007). The genus Vibrio currently encompasses 88 species (Euzeby, 1997), including 10 more new species designated between 2007 and 2008 in the International Journal of Systematic and Evolutionary Microbiology. We used three variable sequence regions of $d$ naJ in 56 different Vibrio species for the design of the PCR primers and real-time PCR probe, and purchased the sequences for these 56 different Vibrio species. The primers and probe we developed were able to amplify DNA from $100 \%$ of the tested $V$. aestuarianus isolates, and our real-time PCR was found to have a specificity of $100 \%$ when testing reference strains belonging to 23 different Vibrio species. The protocol used in specificity assays could be useful for rapid identification of $V$. aestuarianus isolates cultivated on nutrient agar plates since DNA extraction by boiling takes just 10 min and real-time PCR $110 \mathrm{~min}$.

The standard curves generated using real-time PCR with seawater and oyster inoculated with $V$. aestuarianus demonstrated excellent correlations with ten fold dilutions of Vibrio cells, first enumerated under a light microscope in a Malassez chamber. Whatever the nature of the samples tested, efficiencies of the PCR reaction were close to the desired efficiency of $100 \%$ indicating that the increase in $V$. aestuarianus cells is directly proportional to the number of amplification cycles. The results obtained from technical triplicate reactions were very consistent (with a mean variation of about $2 \%$ around the mean $\mathrm{Ct}$ ). Furthermore, the low level of inter-assay variation among the 3 experimental replicates on spiked seawater and oyster samples, with low standard deviations for the calculated $\mathrm{Ct}$ values whatever Vibrio cell concentration, demonstrated the reproducibility and precision of our realtime PCR assay. Precision Ct values were less than 0.4 and 0.6 for spiked seawater and oyster samples, respectively (99\% confidence).

The detection limits of the PCR assay were estimated to be $1.610^{2}$ cells $\mathrm{ml}^{-1}$ and $1.610^{2} \mathrm{cells} \mathrm{mg}^{-1}$ in seawater and oyster samples, respectively, and corresponded to $1.6 \mathrm{~V}$. aestuarianus cells in the PCR reaction in both cases, taking into account the dilution factor used for appropriate template DNA preparation. Nevertheless, at this low concentration, some real-time PCR technical replicates generated no amplification signals at all. When few $V$. aestuarianus cells were added to the PCR reaction, therefore, results appeared to be influenced by a stochastic effect. Indeed 3 out of 9 measurements on seawater samples were found negative with $\mathrm{Ct}$ values below the threshold value, which partly explains the observed increase in standard errors.

In order to quantify $V$. aestuarianus cells in seawater samples or naturally infected oysters, sensitivity assays were performed, using SASW or homogenates of pools of half oysters without $V$. aestuarianus as diluents, to determine standard curves under conditions where PCR inhibitors might be present in the DNA extract samples tested. Sensitivity and reproducibility of the real-time PCR assay were assessed by storing samples for several weeks at $-20^{\circ} \mathrm{C}$ before DNA extraction to test whether retrospective or grouped natural sample analysis would be possible without quantification bias due to freezing. In contrast to the seawater samples, a complete inhibition of PCR was seen with oyster homogenates when the purified DNA was resuspended in the same ultra pure water volume as the seawater samples, i.e. $100 \mu \mathrm{l}$, whatever the dilution of spiked $V$. aestuarianus cells. As mentioned by Cankar and co-workers (Cankar et al., 2006), reliability of quantification by real-time PCR depends crucially on the quality of the sample DNA analysed. When oyster DNA extracts were diluted 10 fold in ultra pure water, PCR inhibitions were only observed in two out of the three pools of spiked oyster homogenate used as diluent. As care was taken to dilute DNA extracts from all samples obtained in the three replicated experiments, using 10 fold more, resulted in successful PCR with no detectable inhibition regardless of the dilution range of spiked $V$. aestuarianus cells as shown by the near $100 \%$ PCR reaction efficiencies. Similar observations have been made by several authors working notably on the detection and quantification of target organisms responsible 
for food poisoning by consumption of raw oysters. For example, Kaufman and co-workers (Kaufmann et al., 2004) showed that there was considerably less inhibition of real-time PCR with mantle fluid than with oyster tissue for $V$. parahaemolyticus quantification, due the damaging effects of the complexity of raw oyster matrix DNA on PCR efficacy. In the present study, inhibition noted in pure and 1 log diluted extract samples seemed more related to an excess of DNA (200 to $1500 \mathrm{ng}$ per PCR reaction) from oyster origin in PCR reaction mix than to the presence of any polymerase inhibitors present in oyster tissues, since the A260/280 purity ratios ranged between 1.5 and 1.8 in all samples indicating that the DNA extraction protocol had worked correctly. Comparing detection limits of our real-time PCR assay with that of Lyon (Lyon, 2001), who was quantifying $V$. cholera in synthetic seawater and raw oyster,


colony forming units (CFU) $\mathrm{ml}^{-1}$ in this previous study. In contrast, a significantly lower detection limit of approximately 4 log of magnitude was obtained in the present study on oyster samples with $1.610^{2}$ cells $\mathrm{mg}^{-1}$ compared with the 6 to $8 \mathrm{CFU} / \mathrm{g}$ in Lyon's study. This discrepancy could be explained by the fact that synthetic medium (alkaline peptone medium) was used to establish standard curves in the cited study rather than complex matrix DNA extracted from raw oysters as in the present one, which required a 100 fold dilution of DNA extracts to overcome PCR inhibitors inherent to oysters tissues.

As a preliminary study, our real-time PCR was also applied to a natural oyster mortality episode. It is important to note that apparently healthy animals were already infected by $V$. aestuarianus the day they arrived at the breeding facility, as revealed by our real-time PCR assay, but at low level and prevalence. The pathogen was also detected and quantified in different samples such as algae for oyster feeding and the water network supplying tanks where oysters were reared, though these samples were taken 7 to 21 days after the onset of mortalities. These findings demonstrate the interest of our PCR assay to deepen future epidemiological studies. One could ask whether the transferred oysters introduced the pathogen into the rearing facilities or whether the pathogen was already present there and exacerbated the spread of $V$. aestuarianus infection in these oysters. Because $V$. aestuarianus was detected on the day of arrival in apparently healthy, but infected, oysters and in one seawater sample from an oyster growout pond only $200 \mathrm{~m}$ from the rearing facility, it seems that the pathogen was already present in the environment.

Because of the rapidity and reliability of the real-time PCR assay method used in this study, just a few hours are required to obtain results compared with two days using classic culture method, this technique may be particularly valuable in mollusc pathology laboratories for monitoring the source and course of infections by $V$. aestuarianus and also for designing appropriate prophylactic control measures.

\section{Acknowledgments}

We thank Helen McCombie for her help with English editing. We are also grateful to Hervé Chaulet for a critical review of the manuscript and to Stratagene Company for funding support, as well as to Julien Normand and Jean-Côme Piquet for their advice during manuscript drafting.

\section{References}

Berthe, F., 2000. Development and validation of DNA-based diagnostic techniques with particular reference to bivalve mollusc pathogens. In: P. Walker, R. Subasinghe (Eds.), DNA-based molecular diagnostic techniques: research needs for standardization and validation of the detection of aquatic animal pathogens and diseases, Vol. 395, FAO, Fisheries Technical Paper, Rome, pp. 64-70.

Blackstone, G.M., Nordstrom, J.L., Vickery, M.C.L., Bowen, M.D., Meyer, R.F., DePaola, A., 2003. Detection of pathogenic Vibrio parahaemolyticus in oyster enrichments by real time PCR. J. Microbiol. Methods. 53, 149-155.

Boettcher, K.J., Barber, B.J., Singer, J.T., 1999. Use of antibacterial agents to elucidate the etiology of Juvenile Oyster Disease (JOD) in Crassostrea virginica and numerical dominance of an alpha proteobacterium in JOD-affected animals. Appl. Environ. Microbiol. 65, 2534-2539.

Boettcher, K.J., Geaghan, K.K., Maloy, A.P., Barber, B.J., 2005. Roseovarius crassostreae sp. nov., a member of the Roseobacter clade and the apparent cause of juvenile oyster disease (JOD) in cultured Eastern oysters. Int. J. Syst. Evol. Microbiol. 55, 1531-1537.

Campbell, M.S., Wright, A.C., 2003. Real-Time PCR analysis of Vibrio vulnificus from oysters. Appl. Environ. Microbiol. 69, 7137-7144. 
Cankar, K., Stebih, D., Dreo, T., Zel, J., Gruden, K., 2006. Critical points of DNA quantification by realtime PCR - effects of DNA extraction method and sample matrix on quantification of genetically modified organisms. BMC Biotechnol. 6, 37.

Elston, R.A., 1993. Infectious diseases of the Pacific oyster, Crassostrea gigas. Annu. Rev. Fish Dis. 3, 259-276.

Euzeby, J.P., 1997. List of bacterial names with standing in nomenclature: a folder available on the Internet. Int. J. Syst. Bacteriology. 47, 590-592.

Faury, N., Saulnier, D., Thompson, F.L., Gay, M., Swings, J., Le Roux, F., 2004. Vibrio crassostreae sp. nov., isolated from the haemolymph of oysters (Crassostrea gigas). Int. J. Syst. Evol. Microbiol. 54, 2137-2140.

Flajnik, M.F., Du Pasquier, L., 2004. Evolution of innate and adaptive immunity: can we draw a line? Trends Immunol. 25, 640-644.

Friedman, C.S., Beaman, B.L., Chun, J., Goodfellow, M., Gee, A., Hedrick, R.P., 1998. Nocardia crassostreae sp. nov., the causal agent of nocardiosis in Pacific oysters. Int. J. Syst. Bacteriology. 48, 237-246.

Friedman, C.S., Beattie J.H., R.A., E., R.P., H., 1991. Investigation of the relationship between the presence of a Gram-positive bacterial infection and summer mortality of the Pacific oyster, Crassostrea gigas Thunberg. Aquaculture. 94, 1-15.

Garnier, M., Labreuche, Y., Garcia, C., Robert, M., Nicolas, J.L., 2007. Evidence for the involvement of pathogenic bacteria in summer mortalities of the Pacific oyster Crassostrea gigas. Microb. Ecol. 53, 187-196.

Gay, M., Berthe, F.C., Le Roux, F., 2004. Screening of Vibrio isolates to develop an experimental infection model in the Pacific oyster Crassostrea gigas. Dis. Aquat. Organ. 59, 49-56.

Gordon, K.V., Vickery, M.C., DePaola, A., Staley, C., Harwood, V.J., 2008. Real-Time PCR assays for quantification and differentiation of Vibrio vulnificus strains in oysters and water. Appl. Environ. Microbiol. 74, 1704-1709.

Heid, C.A., Stevens, J., Livak, K.J., Williams, P.M., 1996. Real time quantitative PCR. Genome Res. 6, 986-994.

Holland, P.M., Abramson, R.D., Watson, R., Gelfand, D.H., 1991. Detection of specific polymerase chain reaction product by utilizing the $5^{\prime}-3^{\prime}$ exonuclease activity of thermus aquaticus DNA polymerase. Proc. Natl. Acad. Sci. U.S.A. 88, 7276-7280.

Kaufmann, A.F., Blackstone, G.M., Vickery, M.C., Bej, A.K., Bowers, J., Bowen, M.D., Meyer, R.F., DePaola, A., 2004. Real-Time PCR quantification of Vibrio parahaemolyticus in oysters using an alternative matrix. J. Food Prot. 67, 2424-2429.

Labreuche, Y., Soudant, P., Goncalves, M., Lambert, C., Nicolas, J.L., 2006a. Effects of extracellular products from the pathogenic Vibrio aestuarianus strain 01/32 on lethality and cellular immune responses of the oyster Crassostrea gigas. Dev. Comp. Immunol. 30, 367-379.

Labreuche, Y., Lambert, C., Soudant, P., Boulo, V., Huvet, A., Nicolas, J.L., 2006b. Cellular and molecular hemocyte responses of the Pacific oyster, Crassostrea gigas, following bacterial infection with Vibrio aestuarianus strain 01/32. Microbs Infect. 8, 2715-2724.

Lacoste, A., Jalabert, F., Malham, S., Cueff, A., Gelebart, F., Cordevant, C., Lange, M., Poulet, S.A., 2001. A Vibrio splendidus strain is associated with summer mortality of juvenile oysters Crassostrea gigas in the Bay of Morlaix (North Brittany, France). Dis. Aquat. Organ. 46, 139-145.

Le Roux, F., Gay, M., Lambert, C., Waechter, M., Poubalanne, S., Chollet, B., Nicolas, J.-L., Berthe, F., 2002. Comparative analysis of Vibrio splendidus-related strains isolated during Crassostrea gigas mortality events. Aquat. Living Resour. 15, 251-258.

Le Roux, F., Goubet, A., Thompson, F.L., Faury, N., Gay, M., Swings, J., Saulnier, D., 2005. Vibrio gigantis sp. nov., isolated from the haemolymph of cultured oysters (Crassostrea gigas). Int. J. Syst. Evol. Microbiol. 55, 2251-2255.

Lyon, W.J., 2001. TaqMan PCR for Detection of Vibrio cholerae O1, O139, Non-O1, and Non-O139 in Pure Cultures, Raw Oysters, and Synthetic Seawater. Appl. Environ. Microbiol. 67, 4685-4693.

McGladdery, S.E., 1999. Shellfish diseases (viral, bacterial and fungal). In: P. T. K. Woo, D. W. Bruno (Eds.), Fish Diseases and Disorders, Vol. 3, CAB International, pp. 723-842.

Nhung, P.H., Shah, M.M., Ohkusu, K., Noda, M., Hata, H., Sun, X.S., lihara, H., Goto, K., Masaki, T., Miyasaka, J., Ezaki, T., 2007. The dnaJ gene as a novel phylogenetic marker for identification of Vibrio species. Syst. Appl. Microbiol. 30, 309-315.

Nordstrom, J.L., Vickery, M.C.L., Blackstone, G.M., Murray, S.L., DePaola, A., 2007. Development of a multiplex real-time PCR assay with an internal amplification control for the detection of total and pathogenic Vibrio parahaemolyticus bacteria in oysters. Appl. Environ. Microbiol. 73, 5840-5847.

Paillard, C., Gausson, S., Nicolas, J.L., le Pennec, J.P., Haras, D., 2006. Molecular identification of Vibrio tapetis, the causative agent of the brown ring disease of Ruditapes philippinarum. Aquaculture. 253, 25 .

Pang, L., Zhang, X.H., Zhong, Y., Chen, J., Li, Y., Austin, B., 2006. Identification of Vibrio harveyi using PCR amplification of the toxR gene. Lett. Appl. Microbiol. 43, 249-255. 
Saulnier, D., Avarre, J.C., Le Moullac, G., Ansquer, D., Levy, P., Vonau, V., 2000. Rapid and sensitive PCR detection of Vibrio penaeicida, the putative etiological agent of Syndrome 93 in New Caledonia. Dis. Aquat. Organ. 40, 109-115.

Sinderman, C.J., 1990. Diseases of Marine Shellfish. Principal Diseases of Marine Fish and Shellfish. Academic Press, San Diego.

Tison, D.L., Seidler, R.J., 1983. Vibrio aestuarianus: a new species from estuarine waters and shellfish. Int. J. Syst. Bacteriology. 33, 699-702. 


\section{Tables}

Table 1

Specificity of the TaqMan PCR assay according to bacterial strains of different origins.

\begin{tabular}{|c|c|c|c|}
\hline Strain & Vibrio species & Source and context of isolation & $\begin{array}{c}\text { Real-time } \\
\text { PCRq } \\
\text { results (+/- } \\
\text { ) }\end{array}$ \\
\hline ATCC35048 $^{\top}$ & V. aestuarianus & Oyster, US & + \\
\hline $02 / 041$ & V. aestuarianus & $\begin{array}{l}\text { C. gigas oyster, } 2002 \text { mortality episode in a } \\
\text { hatchery, Argenton, Finistère, France (Garnier, et } \\
\text { al., 2007) }\end{array}$ & + \\
\hline 05/091 1T1 & V. aestuarianus & $\begin{array}{l}\text { C. gigas oyster, } 2004 \text { mortality episode in an } \\
\text { indoor breeding structure, Ronce Les Bains, } \\
\text { Charente-Maritime, France }\end{array}$ & + \\
\hline 04/021 3Т1 & V. aestuarianus & $\begin{array}{l}\text { C. gigas oyster, } 2004 \text { mortality episode in an } \\
\text { indoor breeding structure, Ronce Les Bains, } \\
\text { Charente-Maritime, France }\end{array}$ & + \\
\hline 04/047 3Т1 & V. aestuarianus & $\begin{array}{l}\text { C. gigas oyster, } 2004 \text { mortality episode in an } \\
\text { indoor breeding structure, Ronce Les Bains, } \\
\text { Charente-Maritime, France }\end{array}$ & + \\
\hline 03/011 1T1 & V. aestuarianus & $\begin{array}{l}\text { C. gigas oyster, } 2003 \text { mortality episode in an } \\
\text { indoor breeding structure, Ronce Les Bains, } \\
\text { Charente-Maritime, France }\end{array}$ & + \\
\hline 03/146 2T1 & V. aestuarianus & $\begin{array}{l}\text { C. gigas oyster, } 2003 \text { mortality episode in an } \\
\text { oyster growout pound, Charente-Maritime, } \\
\text { Angoulins, France }\end{array}$ & + \\
\hline $04 / 0552 \mathrm{~T} 3$ & V. aestuarianus & $\begin{array}{l}\text { C. gigas oyster, } 2004 \text { mortality episode in an } \\
\text { open sea rearing farm, Arcachon Bay, Gironde, } \\
\text { France }\end{array}$ & + \\
\hline 07/083 1T1 & V. aestuarianus & $\begin{array}{l}\text { C. gigas oyster, } 2007 \text { mortality episode in an } \\
\text { open sea rearing farm, Marennes Oleron Bay, } \\
\text { Gironde, France }\end{array}$ & + \\
\hline 07/046 1T1 & V. aestuarianus & $\begin{array}{l}\text { C. gigas oyster, } 2007 \text { mortality episode in an } \\
\text { open sea rearing farm, Olonne, Vendée, France }\end{array}$ & + \\
\hline $07 / 0801 T 2$ & V. aestuarianus & $\begin{array}{l}\text { C. gigas oyster, } 2007 \text { mortality episode in an } \\
\text { open sea rearing farm, Marennes Oleron Bay, } \\
\text { Gironde, France }\end{array}$ & + \\
\hline CECT $4600^{\top}$ & V. tapetis & Tapes philippinarum, clam, France & - \\
\hline LMG $4042^{\top}$ & V. splendidus & Marine fish & - \\
\hline CIP107166 ${ }^{\top}$ & V. lentus & Cultivated oyster, Spain & - \\
\hline LGP $13^{\top}$ & V. gigantis & $\begin{array}{l}\text { C. gigas oyster mortality episode, France (Le Roux et } \\
\text { al., 2005) }\end{array}$ & - \\
\hline LGP $7^{\top}$ & V. crassostreae & $\begin{array}{l}\text { C. gigas oyster mortality episode, France (Faury et } \\
\text { al., 2004) }\end{array}$ & - \\
\hline LMG $20012^{\top}$ & V. tasmaniensis & Atlantic salmon (Salmo salar L.), Tasmania Australia & - \\
\hline LMG $20537^{\top}$ & V. pomeroy & Healthy bivalve larvae (Nodipecten nodosus), Brazil & - \\
\hline LMG $20539^{\top}$ & V. kanaloe & Diseased oyster (Ostrea edulis) larvae, France & - \\
\hline LMG $19999^{\top}$ & V. pacinii & Nauplii of shrimp Penaeus chinensis, China & - \\
\hline LMG $21353^{\top}$ & V. chagasii & Turbot (Scophthalmus maximus) larvae, gut, Norway & - \\
\hline LMG $20547^{\top}$ & V. fortis & Bivalve larvae (Nodipecten nodosus), Brazil & - \\
\hline LMG $21359^{\top}$ & V. cyclitrophicus & Creosote-contaminated marine sediment, US & - \\
\hline LMG $3897^{\top}$ & V. pelagius & Seawater enriched with succinate, US & - \\
\hline$\underset{T}{\text { DSMZ }} 16383$ & V. superstes & Gut of abalone Haliotis rubra, Australia & - \\
\hline DSMZ 19502 & V. mediterranei & Costal marine plankton, Spain & - \\
\hline
\end{tabular}




\begin{tabular}{|c|c|c|c|}
\hline DSMZ 13774 & V. shilonii & Bleached coral Oculina patagonica, Israel & - \\
\hline$\underset{T}{\mathrm{D}} \operatorname{DSMZ} 16639$ & V. gallicus & Gut of abalone Haliotis tuberculata, France & - \\
\hline$\underset{T}{\mathrm{DSMZ}} 17533$ & V. ezurae & Gut of abalone Haliotis diversicolor aquatilis, Japan & - \\
\hline$\underset{T}{\mathrm{DSMZ}} 17185$ & V. xuii & Shrimp culture water, China & - \\
\hline$\underset{T}{\mathrm{DSMZ}} 17184$ & V. brasiliensis & Bivalve larvae (Nodipecten nodosus), Brazil & - \\
\hline DSMZ 14398 & V. penaeicida & Kuruma prawns (Penaeus japonicus), Japan & - \\
\hline$\underset{T}{\mathrm{DSMZ}} 17186$ & V. rotiferianus & Rotifer Brachionus plicatilis culture, Belgium & - \\
\hline CIP $107925^{\top}$ & V. coralliilyticus & $\begin{array}{l}\text { Bleached tissue of coral, Pocillopora damicornis, } \\
\text { Zanzibar }\end{array}$ & - \\
\hline
\end{tabular}


Table 2

Nucleotide sequences and melting temperature $(\mathrm{Tm})$ of primers and probes for realtime PCR reaction.

\begin{tabular}{|c|c|c|c|}
\hline Name & Function & Sequence (5'-3') & $\operatorname{Tm}\left({ }^{\circ} \mathrm{C}\right)$ \\
\hline DNAj aes F1 & Forward primer & GTATGAAATTTTAACTGACCCACAA & 58 \\
\hline DNAj aes R1 & Reverse primer & CAATTTCTTTCGAACAACCAC & 59 \\
\hline DNAj probe & $\begin{array}{l}\text { TaqMan } \\
\text { probe }\end{array}$ & PCR TGGTAGCGCAGACTTCGGCGAC & 71 \\
\hline
\end{tabular}




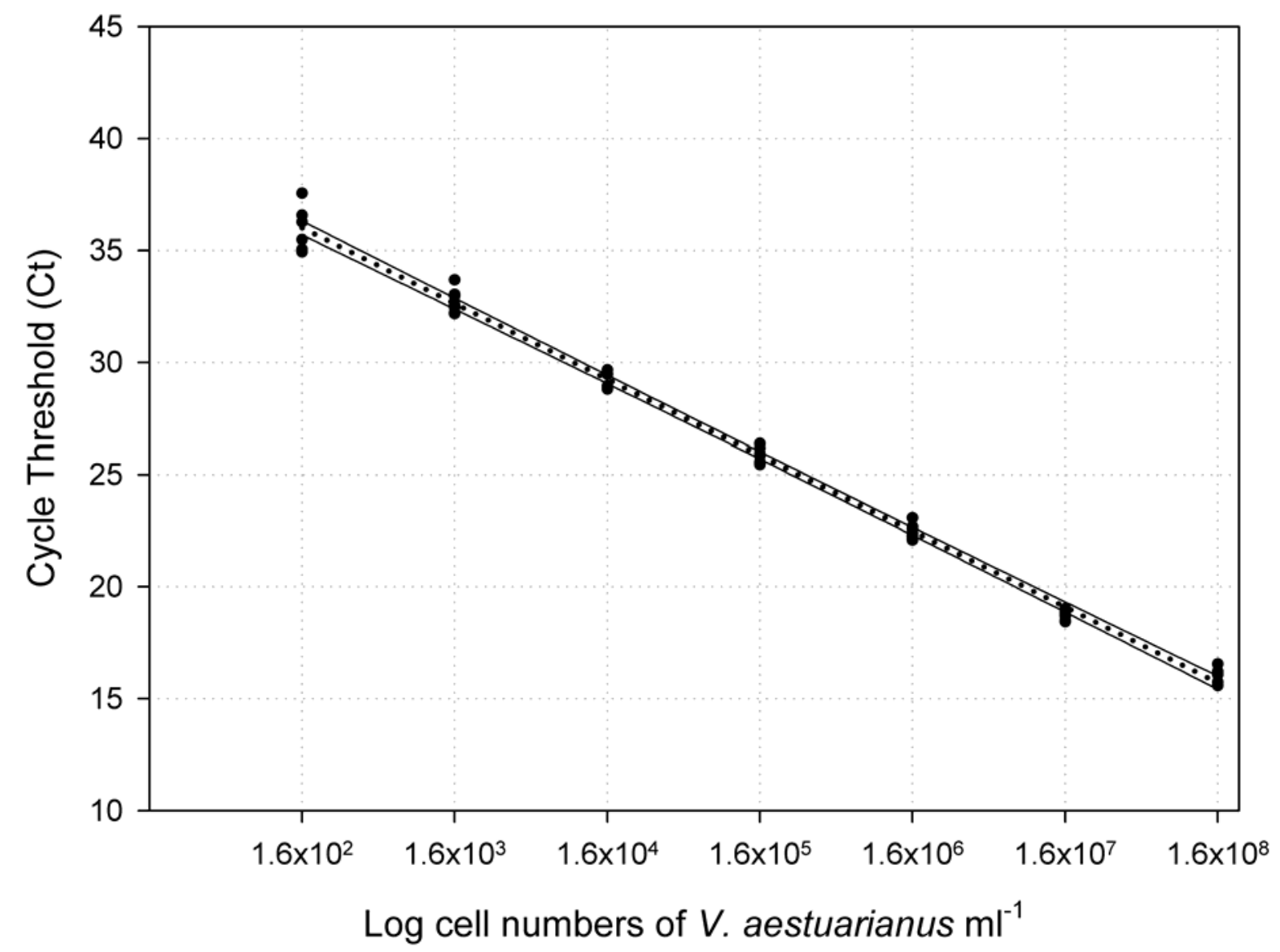

\section{Figure 1}

Standard curves for $V$. aestuarianus real-time PCR in 10 fold dilution of artificially spiked SASW. Standard curves were generated by plotting the log cell number of bacteria versus the threshold cycle $(\mathrm{Ct})$ value. Each plot corresponds to individual $\mathrm{Ct}$ values obtained from the three independent replicate experiments. One linear regression, represented by the dotted line (...), was obtained by collectively treating all the data with $r^{2}$ of 0.995 and PCR reaction efficacy of $97.6 \%$. A confidence line or intervals were established which describes the precision around the regression line at $99 \%$ confidence, represented by a solid line. 


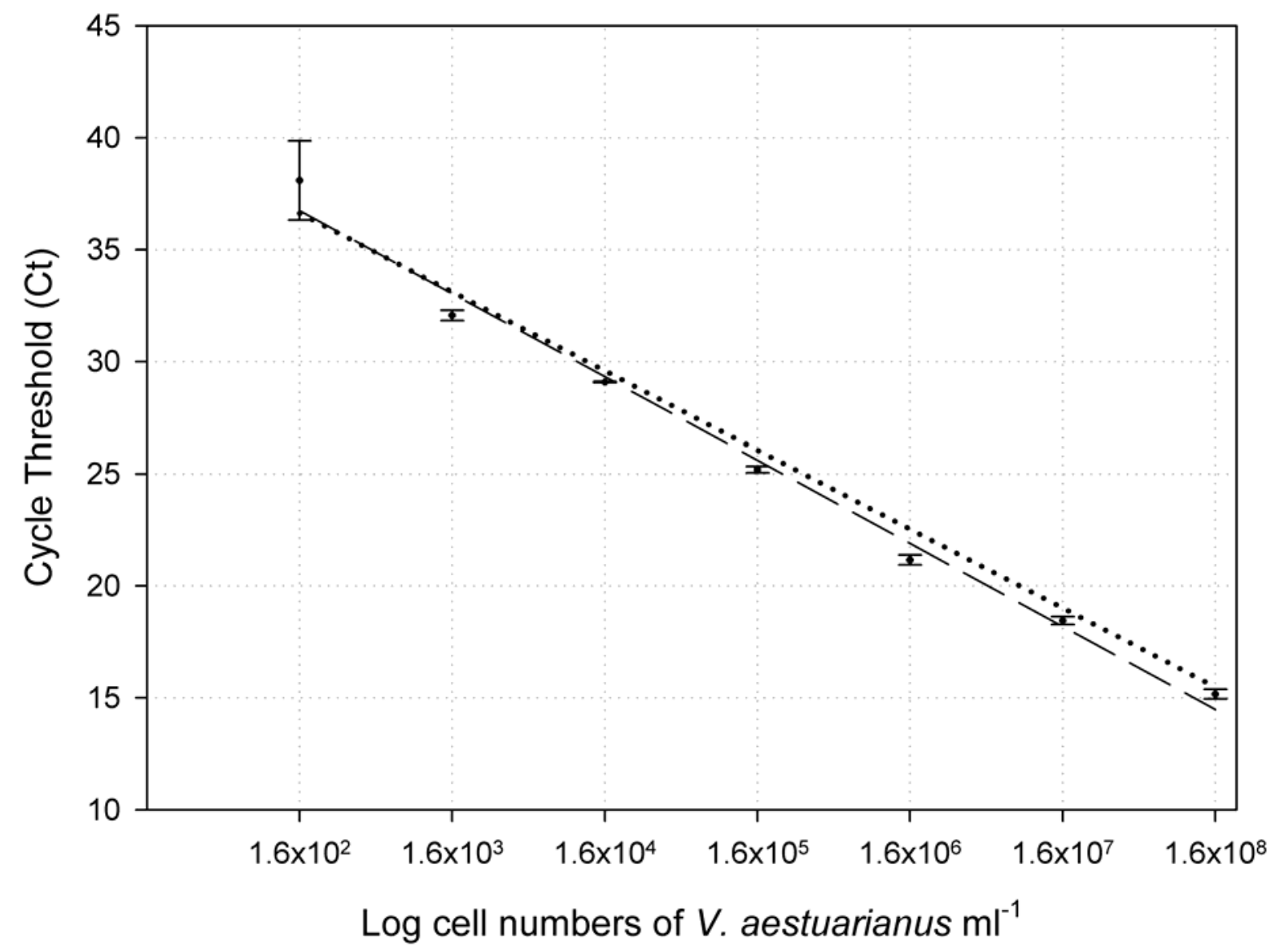

Figure 2

Standard curves showing the log cell numbers plotted against the threshold cycle Ct of ten fold dilutions of $V$. aestuarianus in SASW artificially seeded $(\bullet)$ or not by a mixture of $V$. tapetis and $V$. splendidus type strains at $10^{5}$ cells each. One regression curve, represented by the dotted line (...), was identical to the one represented in Figure 1B, whereas the other, represented by the dashed line (--), defined by $a r^{2}$ of 0.994 and PCR reaction efficacy of $90.6 \%$, was obtained in presence of a mixture of $V$. tapetis and $V$. splendidus cells. Each plot represented by the symbol $(\bullet)$ corresponds to the mean of $\mathrm{Ct}$ values of three technical replicates. Standard deviations are represented by vertical bars. 


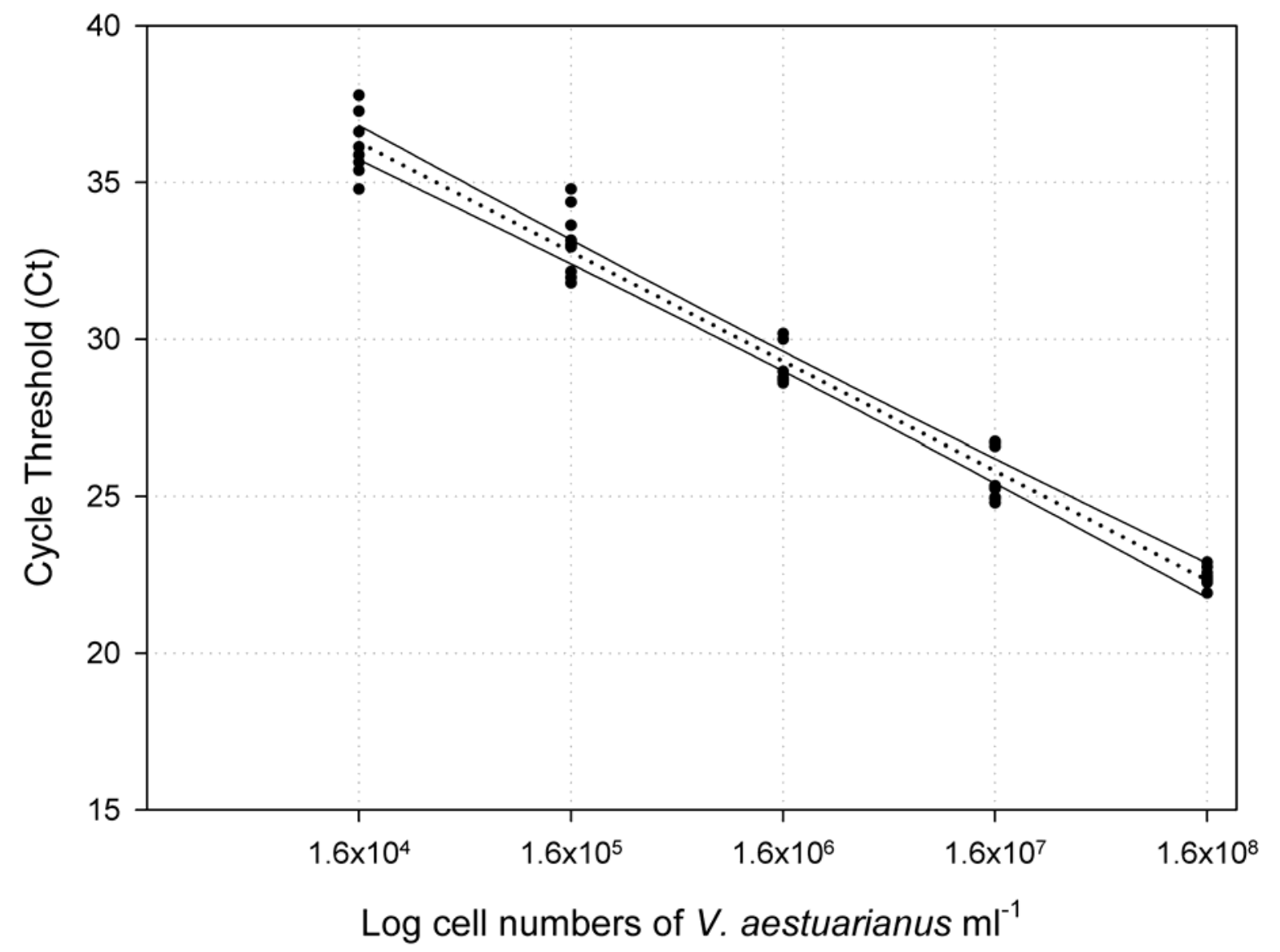

\section{Figure 3}

Standard curves for $V$. aestuarianus real-time PCR in 10 fold dilution of artificially spiked oyster homogenates. Standard curves were generated by plotting the log cell number of bacteria against the threshold cycle $(\mathrm{Ct})$ value. Each plot corresponds to individual $\mathrm{Ct}$ values obtained from the three independent experiments. The linear regression, represented by the dotted line (...), was obtained treating collectively all the data with $r^{2}$ of 0.976 and PCR reaction efficacy of $93.5 \%$. A confidence line or intervals were established which describes the precision around the regression line at $99 \%$ confidence. 


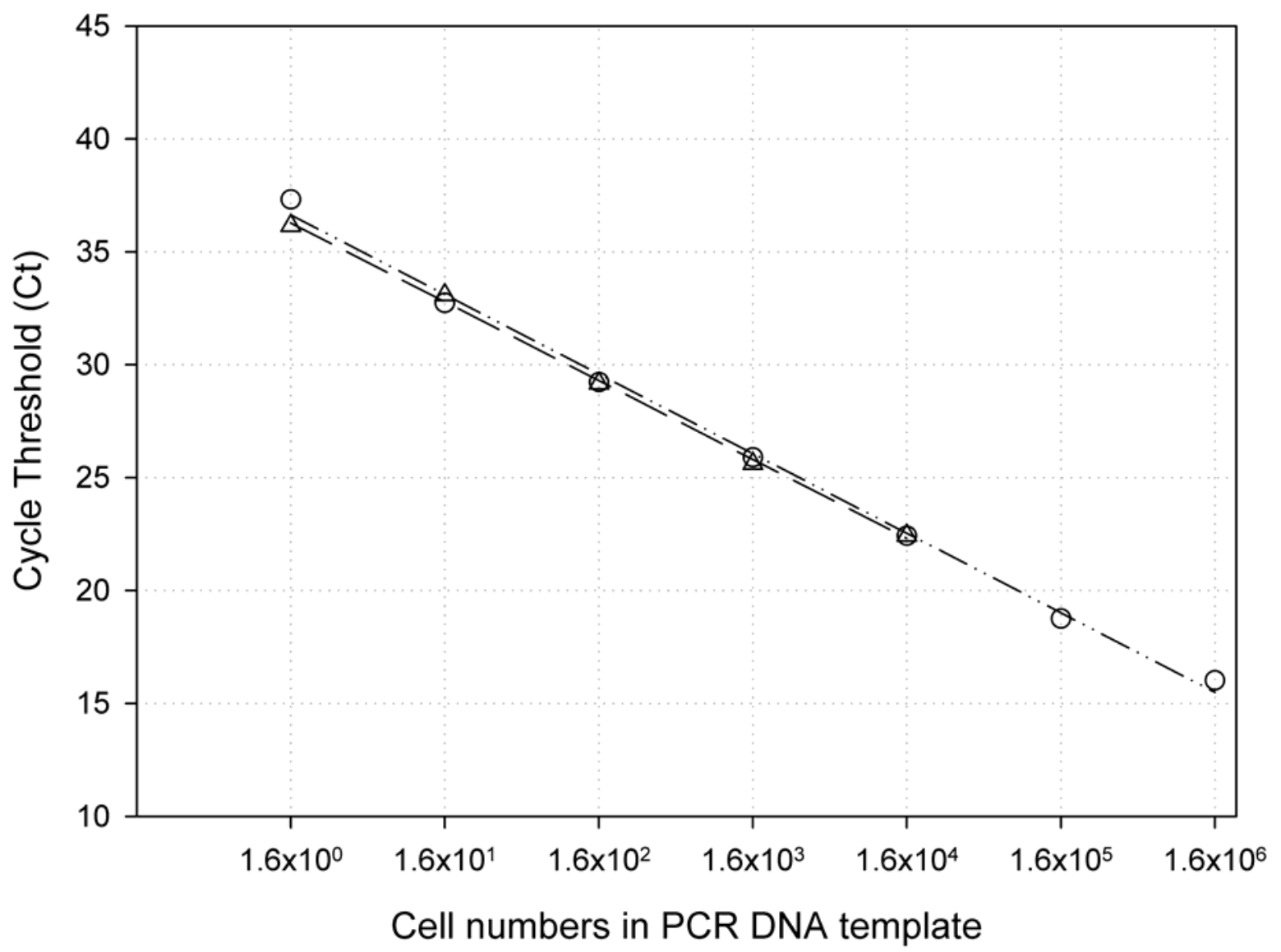

\section{Figure 4}

Standard curves generated by plotting the log cell number of bacteria against the threshold cycle (Ct) value of collectively-treated quantification curves obtained by artificial inoculation with $V$. aestuarianus of either SASW or oyster homogenate represented by symbols (o) and $(\Delta)$ respectively. The dilution factor used for appropriate template DNA preparation (1 or 100 respectively) is taken into account to calculate the log cell number of bacteria in each PCR well. 